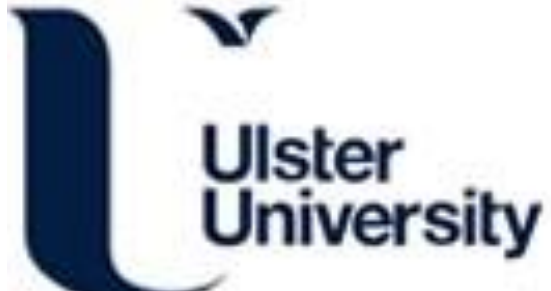

\section{Pharmacological potential of novel agonists for FFAR4 on islet and enteroendocrine cell function and glucose homeostasis}

Mc Closkey, A., Miskelly, M., Flatt, PR., \& McKillop, A. (2020). Pharmacological potential of novel agonists for FFAR4 on islet and enteroendocrine cell function and glucose homeostasis. European Journal of Pharmaceutical Sciences, 142, [105104]. https://doi.org/10.1016/j.ejps.2019.105104

Link to publication record in Ulster University Research Portal

Published in:

European Journal of Pharmaceutical Sciences

Publication Status:

Published (in print/issue): 15/01/2020

DOI:

10.1016/j.ejps.2019.105104

\section{Document Version}

Author Accepted version

\section{General rights}

Copyright for the publications made accessible via Ulster University's Research Portal is retained by the author(s) and / or other copyright owners and it is a condition of accessing these publications that users recognise and abide by the legal requirements associated with these rights.

\section{Take down policy}

The Research Portal is Ulster University's institutional repository that provides access to Ulster's research outputs. Every effort has been made to ensure that content in the Research Portal does not infringe any person's rights, or applicable UK laws. If you discover content in the Research Portal that you believe breaches copyright or violates any law, please contact pure-support@ulster.ac.uk. 
4 Pharmacological potential of novel agonists for FFAR4 on islet and enteroendocrine

5 cell function and glucose homeostasis

6

7 A. G. McCloskey, M. G. Miskelly, P. R. Flatt, A. M. McKillop

8 School of Biomedical Sciences, Ulster University, Cromore Road, Coleraine, BT52 1SA,

$9 \quad$ Northern Ireland.

10

11 Short Title: Selective FFAR4 agonists and beta cell function

13 Corresponding author

14 Aine M. McKillop, School of Biomedical Sciences, Ulster University, Cromore Road,

15 Coleraine, BT52 1SA, Northern Ireland. Tel: +44 (0)28 70123066. Fax: +44(0)2870124965.

16 Email: am.mckillop@ulster.ac.uk

17

18 Word count:

19 Number of references: 34

20 Number of figures: 5

21 Number of tables: 0 
Background: To investigate the metabolic effects of FFAR4-selective agonists on islet and enteroendocrine cell hormone release and the combined therapeutic effectiveness with DPPIV inhibitors.

Methods: Insulinotropic activity and specificity of FFAR4 agonists were determined in clonal pancreatic BRIN-BD11 cells. Expression of FFAR4 was assessed by qPCR and western blotting following agonist treatment in BRIN-BD11 cells and by immunohistochemistry in mouse islets. Acute in-vivo effects of agonists was investigated after intraperitoneal (i.p.) or oral administration in lean and HFF-obese diabetic mice.

Results: GSK137647 $\left(10^{-11}-10^{-4} \mathrm{M}\right)$ and Compound-A $\left(10^{-10}-10^{-4} \mathrm{M}\right)$ stimulated insulin secretion at 5.6mM $(\mathrm{p}<0.05-\mathrm{p}<0.001)$ and $16.7 \mathrm{mM}(\mathrm{p}<0.05-\mathrm{p}<0.001)$ glucose in BRIN-BD11 cells, with no cytotoxicity effects as assessed by MTT. FFAR4 antagonist (AH-7614) abolished the insulintropic effect of GSK137647 ( $p<0.05-p<0.001)$, whilst FFAR1 antagonist (GW1100) had no effect. Incubation of BRIN-BD11 cells with GSK137647 and Compound-A increased FFAR4 $(\mathrm{p}<0.01)$ gene expression at $16.7 \mathrm{mM}$ glucose, with a corresponding increase in FFAR4 $(\mathrm{p}<0.01)$ protein concentrations. FFAR4 upregulation was attenuated under normoglycaemic conditions. Immunohistochemistry demonstrated co-localisation of FFAR4 and insulin in mouse islets. Orally administered GSK137647 or Compound-A $(0.1 \mu \mathrm{mol} / \mathrm{kgBW})$ monotherapy and combinational therapy with Sitagliptin improved glucose tolerance $(p<0.001)$, increased plasma insulin $(p<0.001)$, GLP-1 $(p<0.05)$, GIP $(p<0.05)$, decreased DPPIV activity $(\mathrm{p}<0.01-\mathrm{p}<0.001)$ and induced satiety $(\mathrm{p}<0.001)$ in HFF mice.

Conclusions: Specific FFAR4 agonism improves glucose tolerance through insulin and 45 incretin secretion, with enhanced DPP-IV inhibition in combination with Sitagliptin. 
46 General significance: These findings have for the first time demonstrated that selective

47 FFAR4 activation regulates both islet and enteroendocrine cell function with agonist

48

49

50

51

52

53

54

55 combinational therapy, presenting a promising strategy for the treatment of type-2-diabetes.

Keywords: FFAR4, specificity, insulin, incretin, DPP-IV inhibition, combinational therapy

\section{Introduction:}

FFAR4 (GPR120) is a rhodopsin-like G-protein coupled receptor that is activated by unsaturated fatty acids (C16-22) and long chain saturated fatty acids (C14-18) [1-2]. The human FFAR4 gene is encoded on chromosome 10.q23.3 [3]. With respect to tissue distribution, FFAR4 is extensively expressed in peripheral tissues, intestines, lungs, spleen and pro-inflammatory macrophages [4]. Furthermore, recent studies have demonstrated that FFAR4 is abundantly expressed in the pancreatic islet, with further analysis demonstrating its expression in clonal pancreatic $\beta$-cell lines, including MIN6, RINm5f and INS-1E [5-7].

Previously considered as orphan receptors, recent studies have shown FFAR1 (GPR40), FFAR2 (GPR43), FFAR3 (GPR41), FFAR4 (GPR120) and GPR84 to be activated by free fatty acid (FFA) molecules $[3,4,8]$. FFAR3 and FFAR2 exhibit specificity towards short chain fatty acids, GPR84 is activated by medium chain fatty acids, whereas FFAR1 and FFAR4 are activated by long chain fatty acids [3, 4]. Furthermore, FFAR4 and FFAR1 share 10\% sequence homology and can be activated by similar endogenous ligands (Omega-3-fatty acids), which warrants the utilisation of receptor specific agonists to evaluate the therapeutic potential of FFAR4 $[2,8]$. 
FFAR4 has been hypothesised to act as a lipid sensor in the body, and has been proven to have involvement in the regulation of inflammation, adipogenesis, and glucose homeostasis $[1,7$, 9]. Interestingly, it has been reported that a mutation in the FFAR4 gene (R270H) is linked with the development of obesity. The p. $\mathrm{R} 270 \mathrm{H}$ variant impairs the signalling response of FFAR4 upon FFA binding, with subsequent defects observed to intracellular calcium mobilisation and GLP-1 secretion in intestinal cells $[10,11]$. Further studies have demonstrated that FFAR4 knockdown with siRNA impaired the anti-apoptotic effects of omega-3 fatty acids in serum-starved STC-1 cells. Thus, indicating the potential proliferative and anti-apoptotic effects of FFAR4 in pancreatic beta cells [12].

Numerous studies have identified the involvement of FFAR4 in the gastrointestinal (GI) tract, including the mediation of glucagon-like peptide-1 (GLP-1), gastric inhibitory polypeptide (GIP) and cholecystokinin (CCK) secretion from intestinal L-cells, K-cells and I-cells, with high FFAR4 expression observed in the intestinal STC-1 and GLUTag cell lines [1, 12, 13$]$. FFAR4 activation has been shown to mediate GLP-1 secretion when tested with its endogenous agonist $\alpha$-linolenic acid $[1,14,15]$. However, other studies suggest that FFAR4 has no role in GLP-1 release [16]. Previous findings have shown FFAR4 to mediate insulin-sensitising and anti-inflammatory properties in peripheral tissues [9].

The expression and biological function of FFAR4 in the intestinal tract has been heavily documented, however the role of FFAR4 in pancreatic beta cell function was not investigated until recently [7]. A number of FFAR4 agonists were demonstrated to have regulatory role in glucose dependent insulin secretion in mouse islets, including endogenous docosahexaenoic acid (DHA), eicosapentaenoic acid (EPA), alpha-linolenic acid (ALA) and synthetic GW-9508 $[7,8]$. In addition, these agonists demonstrated insulinotropic and glucose lowering properties in in-vivo [7]. However, the selectivity of endogenous FFAR4 agonists (ALA, DHA, EPA) 
remains uncertain as activation of FFAR1 may contribute to the effects observed, whilst synthetic GW9808 has been shown to exhibit 100-fold greater potency towards FFAR1 over FFAR4 $[17,18]$.

Upon activation, FFAR4 primarily couples to Gaq, which stimulates an array of secondary messenger signalling pathways through phospholipase C (PLC), including intracellular calcium and mitogen-activated protein kinases $[4,7]$. The mechanism of FFAR4 mediated insulin secretion from the pancreatic beta cell is not conclusive; however, studies have shown a range of FFAR4 agonists to induce intercellular calcium release, indicating the potential involvement of inositol trisphosphate on intracellular calcium stores through PLC $\beta$ signalling [7]. FFAR4 activation with ALA and DHA leads to the rapid and transient phosphorylation of the receptor of HEK293 cells [19]. Although FFAR4 has been shown to act predominately through PKC signalling, DHA has also shown to activate G-protein coupled receptor kinase (GPK6) upon FFAR4 phosphorylation, with $\operatorname{Thr}(347)$, Ser (350), and Ser(357) shown to be major phosphorylation sites in the C-terminal tail of FFAR4 [19].

Recently, Oh et al., have reported an orally available, selective, high affinity, small FFAR4 agonist (Compound A) that exhibits a range of anti-diabetic effects [20]. Oral administration of Compound A improved glucose tolerance, insulin sensitivity and exerted anti-inflammatory effects on macrophages in high fat fed obese mice [20]. Sparks et al., recently identified a potent FFAR4 agonist GSK137647 [21] and preliminary in-vitro analysis has demonstrated that GSK137647 augmented insulin secretion in MIN6 cells, with a modest increase in GLP-1 secretion from the NCl-H716 intestinal cell line [21, 22]. In-vivo findings showed that GSK137647 induced GLP-1 release by mouse circumvallate papillae [22]. The highly selective properties of this agonist suggested that it was suitable to evaluate FFAR4 activation in pancreatic beta cells. 
Due to the regulatory role of FFAR4 activation on insulin and incretin secretion $[1,7,14]$, a

117 promising approach using selective FFAR4 agonists combined with a dipeptidyl peptidase-4 (DPP-IV) inhibitor may offer therapeutic potential $[23,24]$. The present study has assessed the effect of potent DPP-IV inhibitor (Sitagliptin) in combination with Compound A and GSK137647 on glucose tolerance and insulin secretion in high fat fed (HFF)-induced diabetic mice. This research aims to investigate the acute metabolic effects and of FFAR4 agonist monotherapy and combinational therapy on islet and enteroendocrine cell function, using pancreatic cells and diabetic mice.

\section{$\underline{2 \text { Materials and methods: }}$}

\subsection{Materials:}

FFAR4 agonists Compound A and GSK137647 were purchased from Cayman Chemicals (Michigan, USA) and Tocris (Bristol, UK) respectively. Sitagliptin phosphate monohydrate was obtained from Apexbio Technology LLC (Texas, USA). Thiazolyl blue tetrazolium bromide (MTT) was received from Sigma (Poole, UK). Rabbit anti-GPR120 polyclonal IgG antibody (H-155) was purchased from Santa Cruz biotechnology (Santa Cruz, CA, USA) and guinea pig anti-insulin from Abcam (Cambridge, UK).

\subsection{Insulin secretion:}

Generation and characterization of the insulin-secreting BRIN-BD11 cells were outlined previously [25]. BRIN-BD11 cells were cultured with RPMI-1640 media (11.1 mM glucose) containing antibiotics (100 U/ml penicillin and $0.1 \mathrm{mg} / \mathrm{ml}$ streptomycin) and $10 \%$ foetal calf serum at $37^{\circ} \mathrm{C}$ in $95 \%$ air and $5 \%$ carbon dioxide. For acute insulin secretion studies, cells were detached using trypsin/EDTA and incubated overnight in 24-well plates with 150,000 cells per 
well. Cells were then pre-incubated for $40 \mathrm{~min}$ at $1.1 \mathrm{mmol} / \mathrm{l}$ glucose in Krebs buffer (comprising $4.7 \mathrm{mmol} / 1 \mathrm{KCL}, 115 \mathrm{mmol} / 1 \mathrm{NaCl}, 1.28 \mathrm{mmol} / \mathrm{CaCl}_{2}, 10 \mathrm{mmol} / 1 \mathrm{NaHCO}, 5 \mathrm{~g} / \mathrm{l}$ bovine serum albumin, $1.2 \mathrm{mmol} / 1 \mathrm{KH}_{2} \mathrm{PO}_{4}, 1.2 \mathrm{mmol} / 1 \mathrm{MgSO}_{4} .7 \mathrm{H} 2 \mathrm{O}, \mathrm{pH}$ 7.4). Test incubations were then performed at $37^{\circ} \mathrm{C}$ for $20 \mathrm{~min}$. Supernatants were removed, then frozen at $-20^{\circ} \mathrm{C}$ until determination of insulin by radioimmunoassay [26]. All FFAR4 ligands (1 $\mathrm{mg} / \mathrm{ml}$ ) were dissolved in 50\% DMSO prior to preparation in Krebs buffer. Compound A and GSK137647 at $10^{-12}-10^{-4} \mathrm{~mol} / 1$ were tested at 5.6 and $16.7 \mathrm{mmol} / 1$ glucose. To determine the selectivity of the agonists towards FFAR4, the FFAR1 antagonist GW1100 $\left(10^{-5} \mathrm{~mol} / \mathrm{l}\right)$, and FFAR4 antagonist AH-7614 $\left(10^{-5} \mathrm{~mol} / \mathrm{l}\right)$ were utilised to antagonise the respective receptors. Receptor antagonists were co-incubated with Compound A and GSK137647 on BRIN-BD11 cells, with insulin secretory responses determined.

\subsection{Cytotoxicity assessment by tetrazolium (MTT):}

BRIN-BD11 cells were cultured overnight in 96-well plates. Incubations were performed as described for insulin secretory analysis. Test solutions were decanted, then $1 \mathrm{mg} / \mathrm{ml}$ of working MTT solution was added and incubated for $2 \mathrm{~h}$ at $37^{\circ} \mathrm{C}$. MTT solution was removed and replaced with $200 \mu 1$ of DMSO. The plate was placed on an orbital shaker for $5 \mathrm{~min}$ to mix the formazan into the solvent. The optical density of each well was recorded at $560 \mathrm{~nm}$ with the background absorbance at $670 \mathrm{~nm}$ removed. The resultant optical density was proportional to 157 the viable cell quantity.

\subsection{Acute effects of FFAR4 agonists in-vivo:}

159 All animal experiments were carried out in accordance with the UK Animal (Scientific Procedures) Act 1986. Male lean and HFF Swiss TO mice (Harlan UK, 30-34 weeks old, 55dark cycle. Drinking water was supplied ad libitum. Animals were maintained on a high fat 
diet (45\% fat, $20 \%$ protein, 35\% carbohydrate; percent of total energy $26.15 \mathrm{~kJ} / \mathrm{g}$; Dietex International Ltd., Witham, UK) from 8 weeks of age for a total of 150 days to evoke dietaryinduced obesity-diabetes (DIO). Another group of mice was maintained on standard rodent diet (10\% fat, $30 \%$ protein, $60 \%$ carbohydrate; percent of total energy $12.99 \mathrm{~kJ} / \mathrm{g}$, Trouw Nutrition,

Cheshire, UK) and used as a model of normal controls. Similar high-fat diets, containing a large percentage of energy from fat, are used routinely in obesity-diabetes research [27-29]. Mice $(\mathrm{n}=6$, fasted $18 \mathrm{~h}$ ) received an oral or IP administration of glucose alone $(18 \mathrm{mmol} / \mathrm{kg}$ body weight) or in combination with FFAR4 agonists $(0.1 \mu \mathrm{mol} / \mathrm{kg}$ body weight $)$. All FFAR4 ligands $(1 \mathrm{mg} / \mathrm{ml})$ were dissolved in 50\% DMSO prior to preparation in saline. Blood samples were obtained by a cut from the tip of the tail vein of conscious mice at the times indicated in Figures, and centrifuged at $16,060 \times g$ for $3 \mathrm{~min}$ at $4^{\circ} \mathrm{C}$. Plasma glucose was measured using an automated glucose oxidase procedure with a Beckman glucose analyser (Beckman-Coulter, High Wycome, UK) and insulin determined by radioimmunoassay [26]. Intestinal hormone secretion was assessed using ELISA; total GLP-1 (Millipore) and total GIP (Millipore). DPPIV activity was evaluated by Gly-Pro-AMC cleavage [30]. In a second series of experiments, $18 \mathrm{~h}$ fasted normal mice were used to assess the effects of agonist treatment on food intake. Mice received oral administration of saline alone $(0.9 \%(\mathrm{w} / \mathrm{v}) \mathrm{NaCl})$ or in combination with agonist $(0.1 \mu \mathrm{mol} / \mathrm{kg}$ body weight $)$ and food intake measured at $30 \mathrm{~min}$ intervals.

\subsection{Gene expression analysis by qPCR:}

mRNA was extracted from clonal pancreatic BRIN-BD11 cells following exposure to agonist treatment, using an RNeasy Mini kit adhering to manufacturer's protocol (Qiagen, UK). Isolated mRNA $(3 \mu \mathrm{g})$ was converted to cDNA using SuperScript II Reserve Transcriptase. Amplification parameters were set at $95^{\circ} \mathrm{C}$ for denaturation, $58^{\circ} \mathrm{C}$ for primer annealing and $72^{\circ} \mathrm{C}$ for elongation for a total of 40 cycles, followed with melting curve analysis, with 
temperature range set at $60^{\circ} \mathrm{C}$ to $90^{\circ} \mathrm{C}$. Values were analysed using the Livak method and normalised to GAPDH expression.

\subsection{FFAR4 protein concentrations using western blotting:}

BRIN-BD11 cells were seeded at a density of 1,000,000 cells per well in 6-well plates and allowed to attach overnight. After $4 \mathrm{~h}$ exposure to $10^{-4} \mathrm{M}$ GSK137647 and Compound A, total protein was extracted at $4^{\circ} \mathrm{C}$ for 10 min using RIPA buffer containing $150 \mathrm{mM} \mathrm{NaCl}, 1.0 \%$ Nonidet P-40, 0.5\% sodium deoxycholate, $0.1 \%$ SDS, $50 \mathrm{mM}$ Tris $\mathrm{HCl}, \mathrm{pH} 7.6$ and protease inhibitor cocktail (Sigma, UK). Total protein concentration was determined using Bradford reagent (Sigma, UK). Equal amounts of protein were prepared in aliquots with Laemmli buffer $(1 \mu \mathrm{g} / \mu \mathrm{l})$, then boiled at $95^{\circ} \mathrm{C}$ for $10 \mathrm{~min}$. Samples $(25 \mu \mathrm{g}$ per well) were loaded onto pre-cast gels (NUPAGE 4-12\% Bis-Tris gels, Invitrogen, UK) and subjected to SDS-PAGE (70 V, 90 min). After transfer to nitrocellulose membrane for $16 \mathrm{~h}$ at $90 \mathrm{~mA}$, membranes were blocked with 5\% skimmed milk and probed with rabbit anti-FFAR4 (1:150) (Santa Cruz, US)/mouse anti- $\beta$-actin (1:2500) (Cell signalling, US). Membranes were probed with ECL horseradish peroxidase donkey anti-rabbit IgG/ECL horseradish peroxidase sheep anti-mouse IgG (1:10000) (GE Healthcare, UK) and detected using Luminata Forte HRP substrate (Millipore, UK), with images captured using the G:BOX Chemi XX9 imager (Syngene, UK). Data were normalised to $\beta$-actin and presented relative to untreated control.

\subsection{Tissue distribution of FFAR4 by immunohistochemistry:}

Pancreatic tissue from lean and HFF NIH Swiss mice was excised and cut at $8 \mu \mathrm{m}$ using a microtome. Sections were placed on slides and dried for $2 \mathrm{~h}$ on a hot plate at $37^{\circ} \mathrm{C}$. After incubation, wax was removed and tissue re-hydrated in ethanol (100\%), ethanol (95\%), ethanol $(80 \%)$ and distilled water for $5 \mathrm{~min}$ each. Slides were incubated in $50 \mathrm{mM}$ sodium citrate for $20 \mathrm{~min}$ at $90^{\circ} \mathrm{C}$ for antigen retrieval. BSA $(2.5 \%)$ was added to each slide $(200 \mu 1)$ for $45 \mathrm{~min}$. 
211 Primary antibodies $(200 \mu \mathrm{l})$ at optimal dilutions (FFAR4 1:100, Insulin 1:300) were added and

212 incubated at $4^{\circ} \mathrm{C}$ overnight. Slides were washed, followed by secondary antibody (1:400)

213 incubation at $37^{\circ} \mathrm{C}$ for $45 \mathrm{~min}$. The slides were washed, then DAPI $(0.1 \mu \mathrm{g} / \mathrm{ml})$ added and

214 incubated at $37^{\circ} \mathrm{C}$ for $15 \mathrm{~min}$. Slides were washed, then mounted.

\section{$215 \quad 2.8$ Statistics}

216 All data was analysed with Prism (v.5.0, GraphPad Software Inc. CA, USA) and expressed 217 as mean \pm S.E.M. All in-vivo glucose tolerance test data (glucose, insulin, GLP-1, GIP and considered to be statistically significant.

\section{Results:}

\subsection{Determination of FFAR4 agonist selectivity on insulin secretion.}

The insulinotropic response and specificity of the novel synthetic FFAR4 agonists (Compound A, GSK137647) at $10^{-12}-10^{-4} \mathrm{~mol} / 1$ were assessed using clonal pancreatic BRIN-BD11 cells. At 5.6 mM glucose, Compound A at $10^{-10}-10^{-4} \mathrm{~mol} / \mathrm{l}$ augmented insulin secretion by $1.2-$ to 1.9-fold $(p<0.05-p<0.001)$, with a half maximal effective concentration $\left(E_{50}\right)$ of $2.9 \times 10^{-7}$ mol/1, while GSK137647 was more potent $\left(\mathrm{EC}_{50}\right.$ of $\left.2.2 \times 10^{-7} \mathrm{~mol} / \mathrm{l}\right)$ with a 1.5 - to 2.1 -fold increase at $10^{-8}-10^{-4} \mathrm{~mol} / 1(\mathrm{p}<0.05-\mathrm{p}<0.001)$ (Figure $\left.1 \mathrm{~A}, \mathrm{~B}\right)$. At $16.7 \mathrm{mM}$ glucose, both agonists exhibited enhanced insulinotropic activity. Compound $A$ at $10^{-7}-10^{-4} \mathrm{~mol} / \mathrm{l}$ augmented insulin secretion from 1.8- to 2.4 fold $(\mathrm{p}<0.05-\mathrm{p}<0.001)$ and GSK137647 at $10^{-11}-10^{-4} \mathrm{~mol} / \mathrm{l}$ 
enhanced insulin secretion by 1.4 - to 2.8 -fold $(\mathrm{p}<0.05-\mathrm{p}<0.001)$, with $\mathrm{EC}_{50}$ values of $3.0 \times 10^{-}$ ${ }^{8} \mathrm{~mol} / \mathrm{l}$ (Compound A) and $1.2 \times 10^{-10} \mathrm{~mol} / \mathrm{l}$ (GSK137647) (Figure $\left.1 \mathrm{C}, \mathrm{D}\right)$. Neither agonist affected cell viability when assessed by MTT (Figure 1).

To investigate the selectivity of the agonists, both Compound A and GSK137647 were coincubated with selective FFAR1 and FFAR4 antagonists. The insulin secretory response of Compound A and GSK137647 was not influenced by incubation with the FFAR1 antagonist GW1100 $\left(10^{-5} \mathrm{~mol} / \mathrm{l}\right)$, with similar insulinotropic responses being observed in the presence and in the absence of GW1100 (Figure 1). In contrast, the FFAR4 antagonist AH-7614 $\left(10^{-5} \mathrm{~mol} / \mathrm{l}\right)$ significantly impaired the insulinotropic responses of Compound A and GSK137647. At 5.6 $\mathrm{mM}$ glucose in the presence of the FFAR4 antagonist, Compound A $\left(10^{-6}-10^{-4} \mathrm{~mol} / \mathrm{l}\right)$ augmented insulin secretion by 1.25 - to 1.3 -fold ( $p<0.05$ ), corresponding to a $65 \%$ decrease in insulin output compared with control. Furthermore, the insulinotropic effect of GSK137647 was abolished in the presence of the FFAR4 antagonist (Figure $1 \mathrm{~A}, \mathrm{~B}$ ). At $16.7 \mathrm{mM}$ glucose in the presence of the FFAR4 antagonist, Compound $\mathrm{A}$ at $10^{-5}-10^{-4} \mathrm{~mol} / 1$ increased insulin secretion by 1.7 - to 1.8 -fold $(\mathrm{p}<0.05)$, corresponding to a $65 \%$ reduction compared to agonist alone. GSK 137647 at $10^{-7}-10^{-4} \mathrm{~mol} / 1$ only augmented insulin secretion by $1.7-$ to 2.1 fold in the presence of the antagonist $(\mathrm{p}<0.01)$ (Figure $1 \mathrm{C}, \mathrm{D})$, reflecting a $40 \%$ decrease in insulinotropic action.

\subsection{Expression of FFAR4 in high fat fed pancreatic tissue and BRIN-BD11 cells:}

Immunohistochemistry revealed high expression and areas of co-localisation of FFAR4 and insulin in pancreatic islets from lean and HFF mice (Figure $2 \mathrm{~A}-\mathrm{H}$ ). The pancreatic BRINBD11 cell line was used to confirm FFAR4 gene expression in pancreatic beta cells. At 5.6 mM glucose, FFAR4 agonists Compound A $(\mathrm{p}<0.05)$ and GSK137647 $(\mathrm{p}<0.05)$ downregulated FFAR4 receptor mRNA expression in BRIN-BD11 cells (Figure 2 I). When 
exposed to $16.7 \mathrm{mM}$ glucose, FFAR4 agonists (Compound $\mathrm{A}(\mathrm{p}<0.01)$ and GSK137647

$(\mathrm{p}<0.01)$ increased FFAR4 mRNA expression (Figure $2 \mathrm{~J})$. Western blotting was conducted to upregulated FFAR4 protein by 1.9 fold $(\mathrm{p}<0.05)$ in hyperglycaemic conditions, whilst

Compound A had no significant effect (Figure 2 L). FFAR4 protein concentrations were not altered by either agonist under normoglycaemic ( $5.6 \mathrm{mM}$ glucose) conditions (Figure $2 \mathrm{~K}$ ).

\subsection{Acute effects of FFAR4 agonists on glucose tolerance and insulin secretion in-vivo}

An oral glucose tolerance test (OGTT) was performed to assess the anti-diabetic activity of Compound A and GSK137647 in fasted HFF mice. Compound A and GSK137647 were assessed alone or in combination with the DPP-IV inhibitor (Sitagliptin). FFAR4 antagonist AH-7614 was utilised to determine agonist specificity in-vivo. Oral administration of Compound A and GSK13647 improved glucose tolerance $(\mathrm{p}<0.05-0.001)$ (Figure 3 A, C), with AUC data showing decreases with Compound A and GSK137647 by $26 \%(\mathrm{p}<0.05)$ and $18 \%$ $(p<0.05)$ respectively (Figure $3 \mathrm{E}, \mathrm{G})$. In combination with Sitagliptin, these compounds exhibited a further improvement on glucose excursion by 5-11\%. The FFAR4 antagonist impaired the glucose lowering properties of Compound A and GSK137647 by $77 \%(\mathrm{p}<0.05)$ and $89 \%(p<0.05)$ respectively (Figure 3 A, C).

These effects on blood glucose control were accompanied by relative changes in insulin secretion. Agonising FFAR4 with Compound A $(p<0.05)$ and GSK137647 $(p<0.001)$ increased plasma insulin by $20 \%$ and $54 \%$ when assessed with AUC data (Figure 3 F, H). Compound A in combination with Sitagliptin demonstrated an additive $12 \%$ insulinotropic effect compared to Compound A alone, whilst GSK137647 combinational therapy resulted in a 9\% reduction compared to agonist alone (Figure 3 B, D). The FFAR4 antagonist AH-7614 inhibited the insulinotropic response of Compound A by $30 \%$ and GSK137647 by $76 \%(p<0.001)$. 
282

283

284

285

286

287

288

289

290

291

292

293

294

295

296

297

298

299

300

301

302

303

GSK137647 increased plasma GLP-1 $(p<0.05)$ and GIP $(p<0.05)$, whilst Compound A increased plasma GLP-1 $(\mathrm{p}<0.05)$ but had no effect GIP secretion (Figure 4 A, B, D, E). GSK137647 $(\mathrm{p}<0.01)$ and Compound A $(\mathrm{p}<0.01)$ reduced DPP-IV activity, with activity further diminished when administered in combination with Sitagliptin $(p<0.001)$ (Figure $4 \mathrm{C}$, F).

In addition to oral treatment, Compound A and GSK137647 were administered also by intraperitoneal injection to lean mice (Figure 5 A). Compound A significantly improved glucose excursion $(p<0.01)$, with GSK137647 $(p<0.05)$ eliciting a similar response.

\subsection{Acute effects of FFAR4 agonists on appetite suppression in lean Swiss TO mice}

Compound A induced satiety after 30 min with further effects observed over the $3 \mathrm{~h}$ time period $(p<0.05-p<0.001)$ (Figure 5 B). Sitagliptin impaired the satiation effect of Compound A at 60 min. GSK137647 inhibited food intake after $30 \mathrm{~min}$, with lasting effects throughout the experimental timeframe $(\mathrm{p}<0.01-\mathrm{p}<0.001)$ (Figure 5 C). Combination of GSK137647 with Sitagliptin impaired the appetite suppressive effects of the agonist from $60 \mathrm{~min}$ to $180 \mathrm{~min}$ $(\mathrm{p}<0.05-\mathrm{p}<0.001)$.

\section{Discussion:}

Recent interest in long chain fatty acid receptors has intensified due to identification of their involvement in the maintenance of glucose homeostasis through GPCR signalling. FFAR1 (GPR40) [31], GPR55 [32, 33] and GPR119 [33, 34] have been previously reported to regulate islet function and hormone secretion. In particular, orally administered FFAR1 agonist TAK875 (Fasiglifam) entered stage III clinical trials with promising anti-diabetic effects of equal 
potency to the sulphonylurea glimepiride, whilst omitting the risk of hypoglycaemia $[35,36]$.

FFAR4 (GPR120) is a rhodopsin (class A) type receptor which has recently been shown to have anti-diabetic properties through the regulation of insulin and incretin secretion $[1,7,8]$. Recent studies have identified the expression and involvement of FFAR4 in the pancreatic islet and intestinal tract, with expression also identified in adipose tissue, lungs and proinflammatory macrophages. FFAR4 shares $10 \%$ homology with FFAR1 and has high affinity for long chain fatty acids. However, many FFAR4 agonists can act as dual agonists with FFAR1, such as synthetic GW9508, therefore the identification of selective FFAR4 agonists is required to fully evaluate the role of the receptor in the maintenance of glucose homeostasis $[7,8]$.

In the present study, the therapeutic potential of two novel synthetic agonists (Compound A, GSK137647), which have been shown to exhibit selective properties towards FFAR4, were assessed [20-21]. Insulin secretion studies demonstrated that both agonists enhanced glucose stimulated insulin secretion from pancreatic BRIN-BD11 cells. Compound A and GSK13647 displayed similar potencies at basal glucose levels $\left(\mathrm{EC}_{50}\right.$ of $\left.\sim 10^{-7} \mathrm{~mol} / \mathrm{l}\right)$. Stimulatory glucose concentrations, GSK137647 exhibited an $\mathrm{EC}_{50}$ of $10^{-10} \mathrm{~mol} / \mathrm{l}$, compared with an $\mathrm{EC}_{50}$ of $10^{-8}$ mol/1 for Compound A. Neither agonist imparted adverse effects on cell viability as assessed using MTT.

To demonstrate the selectivity of the novel agonists towards FFAR4, potent antagonists for FFAR4 and FFAR1 were employed. In the presence of FFAR1 antagonist (GW1100), the insulin secretory responses to both Compound A and GSK137647 was relatively unaffected. In contrast, the FFAR4 antagonist (AH-7614) impaired the insulinotropic properties of both agents, suggesting that the two agonists stimulate glucose dependent insulin secretion through 
FFAR4 and not FFAR1 in the pancreatic beta cell. Numerous endogenous FFAR4 ligands have been shown to stimulate other fatty acids receptors, including FFAR1 [3, 8].

Immunohistochemistry demonstrated the highly abundant expression and co-localisation of FFAR4 and insulin in both the pancreas of lean and diabetic mice. Consistent with this, gene expression analysis demonstrated an upregulation of FFAR4 in BRIN-BD11 cells exposed to hyperglycaemia, suggesting that FFAR4 may have a regulatory role in islets exposed to diabetic stress factors. Interestingly, agonist treatment under normoglycaemic conditions significantly attenuated FFAR4 gene expression, with no effect demonstrated on FFAR4 protein concentrations. The glucose responsive properties of the receptor expression promotes FFAR4 as a novel therapeutic target.

In HFF mice, both Compound A and GSK137647 demonstrated acute glucose lowering and insulinotropic properties. Previously, FFAR4 activation was shown to augment glucagon release from pancreatic alpha cells [38]. Although glucagon opposes the biological actions of insulin, improved glucose tolerance is exhibited upon FFAR4 agonist treatment. This indicates superior secretory actions of FFAR4 agonism on insulin releasing beta cells. Interestingly, FFAR4 activation has also been shown to inhibit somatostatin release from pancreatic delta cells, which may have indirectly enhanced the insulinotropic actions of FFAR4 agonists observed in this study [39]. Although numerous glucoregulatory hormones are released upon FFAR4 activation, the anti-inflammatory effects and potentiation of glucose uptake in peripheral tissues may have also attributed to the glucose lowering effects exhibited by FFAR4 [9].

Conflicting results have been reported of the effect of FFAR4 activation of GLP-1 secretion $[1,16]$. In the present study, GSK137647 was shown to induce GLP-1 and GIP secretion, whilst Compound A only stimulated GLP-1 secretion. To prolong the bioactivity of endogenously 
released incretins, the DPP-IV inhibitor Sitagliptin was examined in combination with the FFAR4 agonists. Under these conditions, Compound A and GSK137647 exhibited enhanced glucose lowering capabilities, by stimulating incretin (GLP-1, GIP) and insulin secretion through FFAR4 activation, supplemented with prolonged incretin action through DPP-IV inhibition. DPP-IV inhibition however countered the inhibitory effects of both FFAR4 agonists on feeding activity. Further studies are required to fully understand the mechanism but inhibition of DPP-IV-mediated degradation of PYY(1-36) to the active form PYY(3-36) seems likely [40].

To establish that the glucose lowering properties of the agonists was not based solely on incretin secretion, each agonist was administered i.p. in combination with glucose. Both GSK137647 and Compound A improved glucose excursion confirming that FFAR4 activation also directly stimulates beta cell function. The selectivity of the novel agonists was tested using the FFAR4 antagonist AH-7614, which significantly impaired the insulinotropic and glucose lowering capabilities of GSK137647 and Compound A.

In conclusion, selective FFAR4 agonists enhance glucose stimulated insulin secretion in a concentration-dependent manner, whilst exhibiting no affinity for FFAR1. Expression analysis demonstrated glucose responsive properties of FFAR4 expression under hyperglycaemic stress, a novel finding which may aid the development of future anti-diabetic therapeutics. Activation of FFAR4 was associated with acute stimulatory effects on GLP-1 and GIP secretion. GSK137647 was the most potent agonist in terms of insulin and incretin secretion, suggesting that this agonist should be considered for further investigation. In addition, it has been shown for the first time that FFAR4 agonist combinational therapy with sitagliptin further improves glucose tolerance and may provide a novel approach for the treatment of type 2 diabetes. 
377 These studies were supported by Diabetes UK. AGMC conducted the investigation, 378 methodology, validation, formal analysis and writing - original draft. MGM conducted the 379 investigation. PRF involved in the writing- review and editing and supervision. AMMK 380 involved in the conceptualization, formal analysis, supervision writing - review and editing.

\section{$\underline{\text { References }}$}

1. Hirasawa A, Tsumaya K, Awaji T, Katsuma S, Adachi T, Yamada M et al. Free fatty acids regulate gut incretin glucagon-like peptide-1 secretion through GPR120. Nat Med 200511 90-94.

2. Ulven, T. and Christiansen, E. Dietary Fatty Acids and Their Potential for Controlling Metabolic Diseases Through Activation of FFA4/GPR120. Annu Rev Nutr 2015 35(1) 239263.

3. Ichimura A, Hirasawa A, Hara T, Tsujimoto G. Free fatty acid receptors act as nutrient sensors to regulate energy homeostasis. Prostaglandins Other Lipid Mediat 2009 89 82-88.

4. Milligan G, Shimpukade B, Ulven T. and Hudson, B. Complex Pharmacology of Free Fatty Acid Receptors. Chem. Rev.2017 117(1) 67-110.

5. Dhayal S, Welters HJ, Morgan NG. Structural requirements for the cytoprotective actions of mono-unsaturated fatty acids in the pacreatic beta-cell line, BRIN-BD11. $B r J$ Pharmacol 2008153 1718-1727.

6. Gehrmann, W., Elsner, M. and Lenzen, S. Role of metabolically generated reactive oxygen species for lipotoxicity in pancreatic $\beta$-cells. Diabetes Obes Metab 201012 149-158. 
7. Moran BM, Abdel-Wahab YH, Flatt PR, McKillop AM. Evaluation of the insulin-releasing and glucose-lowering effects of GPR120 activation in pancreatic beta-cells. Diabetes Obes Metab 201416 1128-1139.

8. Moran BM, Flatt PR, McKillop AM. G protein-coupled receptors: signalling and regulation by lipid agonists for improved glucose homoeostasis. Acta Diabetol 201653 177-188.

9. Oh DY, Talukdar S, Bae EJ, Imamura T, Morinaga H, Fan W et al. GPR120 is an omega3 fatty acid receptor mediating potent anti-inflammatory and insulin-sensitizing effects. Cell 2010142 687-698.

10. Ichimura A, Hirasawa A, Poulain-Godefroy O, Bonnefond A, Hara T, Yengo L et al. Dysfunction of lipid sensor GPR120 leads to obesity in both mouse and human. Nature 2012483 350-354.

11. Bonnefond A, Lamri A, Leloire A, Vaillant E, Roussel R, Levy-Marchal C et al. Contribution of the low-frequency, loss-of-function p.R270H mutation in FFAR4 (GPR120) to increased fasting plasma glucose levels. J Med Genet 201552 595-598.

12. Iakoubov R, Izzo A, Yeung A, Whiteside CI, Brubaker PL. Protein kinase Czeta is required for oleic acid-induced secretion of glucagon-like peptide-1 by intestinal endocrine L cells. Endocrinology 2007148 1089-1098.

13. Sankoda A, Harada N, Iwasaki K, Yamane S, Murata Y, Shibue K et al. Long-Chain Free Fatty Acid Receptor GPR120 Mediates Oil-Induced GIP Secretion Through CCK in Male Mice. Endocrinology 2017158 1172-1180.

14. Tanaka T, Yano T, Adachi T, Koshimizu TA, Hirasawa A, Tsujimoto G. Cloning and characterization of the rat free fatty acid receptor GPR120: in vivo effect of the natural ligand on GLP-1 secretion and proliferation of pancreatic beta cells. Naunyn Schmiedebergs Arch Pharmacol 2008377 515-522. 
15. Bhaswant, M., Poudyal, H. and Brown, L. Mechanisms of enhanced insulin secretion and sensitivity with n-3 unsaturated fatty acids. J. Nutr. Biochem 2015 26(6) 571-584.

16. Paulsen SJ, Larsen LK, Hansen G, Chelur S, Larsen PJ, Vrang N. Expression of the fatty acid receptor GPR120 in the gut of diet-induced-obese rats and its role in GLP-1 secretion. PLoS One 2014 9: e88227.

17. Briscoe C, Tadayyon M, Andrews J, Benson W, Chambers J, Eilert M et al. The Orphan G Protein-coupled Receptor GPR40 Is Activated by Medium and Long Chain Fatty Acids. $J$. Biol. Chem 2003 278(13) 11303-11311.

18. Christiansen E, Watterson K, Stocker C, Sokol E, Jenkins L, Simon K et al. Activity of dietary fatty acids on FFA1 and FFA4 and characterisation of pinolenic acid as a dual FFA1/FFA4 agonist with potential effect against metabolic diseases. Br J Nutr 2015 113(11) $1677-1688$.

19. Burns RN, Singh M, Senatorov IS, Moniri NH. Mechanisms of homologous and heterologous phosphorylation of FFA receptor 4 (GPR120): GRK6 and PKC mediate phosphorylation of $\operatorname{Thr}(3)(4)(7), \operatorname{Ser}(3)(5)(0)$, and $\operatorname{Ser}(3)(5)(7)$ in the C-terminal tail. Biochem Pharmacol 201487 650-659.

20. Oh DY, Walenta E, Akiyama TE, Lagakos WS, Lackey D, Pessentheiner AR et al. A Gpr120-selective agonist improves insulin resistance and chronic inflammation in obese mice. Nat Med 201420 942-947.

21. Sparks SM, Chen G, Collins JL, Danger D, Dock ST, Jayawickreme C et al. Identification of diarylsulfonamides as agonists of the free fatty acid receptor 4 (FFA4/GPR120). Bioorg Med Chem Lett 201424 3100-3103.

22. Martin C, Passilly-Degrace P, Chevrot M, Ancel D, Sparks SM, Drucker DJ et al. Lipidmediated release of GLP-1 by mouse taste buds from circumvallate papillae: putative involvement of GPR120 and impact on taste sensitivity. J Lipid Res 201253 2256-2265. 
23. Drucker D, Easley C, Kirkpatrick P. Sitagliptin. Nat Rev Drug Discov 20076 109-110.

24. Tanaka H, Yoshida S, Minoura H, Negoro K, Shimaya A, Shimokawa T et al. Novel GPR40 agonist AS2575959 exhibits glucose metabolism improvement and synergistic effect with sitagliptin on insulin and incretin secretion. Life Sci 201494 115-121.

25. McClenaghan NH, Barnett CR, Ah-Sing E, Abdel-Wahab YH, O'Harte FP, Yoon TW, Swanston-Flatt SK \& Flatt PR. Characterization of a novel glucose-responsive insulinsecreting cell line, BRIN-BD11, produced by electrofusion. Diabetes 199645 1132-1140.

26. Flatt PR, Bailey CJ. Abnormal plasma glucose and insulin responses in heterozygous lean (ob/+) mice. Diabetologia 198120 573-577.

27. West DB, Waguespack J, McCollister S. Dietary obesity in the mouse: interaction of strain with diet composition. Am. J. Physiol 1995268 658-665.

28. Black BL, Croom J, Eisen EJ, Petro AE, Edwards CL, Surwit RS. Differential effects of fat and sucrose on body composition in A/J and C57BL/6 mice. Metabolism. 1998471354 1359.

29. Buettner R, Schölmerich J, Bollheimer LC. High-fat diets: modeling the metabolic disorders of human obesity in rodents. Obesity (Silver Spring) 200715 798-808.

30. Davis JA, Singh S, Sethi S, Roy S, Mittra S, Rayasam G et al. Nature of action of Sitagliptin, the dipeptidyl peptidase-IV inhibitor in diabetic animals. Indian J Pharmacol 201042 229-233.

31. Itoh Y, Kawamata Y, Harada M, Kobayashi M, Fujii R, Fukusumi S et al. Free fatty acids regulate insulin secretion from pancreatic beta cells through GPR40. Nature 2003422 173176.

32. McKillop AM, Moran BM, Abdel-Wahab YH, Flatt PR. Evaluation of the insulin releasing and antihyperglycaemic activities of GPR55 lipid agonists using clonal beta-cells, isolated pancreatic islets and mice. Br J Pharmacol 2013170 978-990. 
33. McKillop AM, Moran BM, Abdel-Wahab YH, Gormley NM, Flatt PR. Metabolic effects of orally administered small-molecule agonists of GPR55 and GPR119 in multiple lowdose streptozotocin-induced diabetic and incretin-receptor-knockout mice. Diabetologia 201659 2674-2685.

34. Moran BM, Abdel-Wahab YH, Flatt PR, McKillop AM. Activation of GPR119 by fatty acid agonists augments insulin release from clonal beta-cells and isolated pancreatic islets and improves glucose tolerance in mice. Biol Chem 2014395 453-464.

35. Marcinak J, Cao C, Lee D, Ye Z. Fasiglifam for glycaemic control in people with type 2 diabetes: A phase III, placebo-controlled study. Diabetes Obes Metab 201719 1714-1721.

36. Peng XV, Marcinak JF, Raanan MG, Cao C. Combining the G-protein-coupled receptor 40 agonist fasiglifam with sitagliptin improves glycaemic control in patients with type 2 diabetes with or without metformin: A randomized, 12-week trial. Diabetes Obes Metab $2017191127-1134$.

37. Otieno MA, Snoeys J, Lam W, Ghosh A, Player MR, Pocai A et al. Fasiglifam (TAK-875): Mechanistic Investigation and Retrospective Identification of Hazards for Drug Induced Liver Injury. Toxicol Sci 2018163 374-384.

38. Suckow A, Polidori D, Yan W, Chon S, Ma J, Leonard J et al. Alteration of the Glucagon Axis in GPR120 (FFAR4) Knockout Mice. J. Biol. Chem 2014 289(22) 15751-15763.

39. Stone V, Dhayal S, Brocklehurst K, Lenaghan C, Sörhede Winzell M, Hammar M, et al. GPR120 (FFAR4) is preferentially expressed in pancreatic delta cells and regulates somatostatin secretion from murine islets of Langerhans. 2014 Diabetologia, 57(6) 11821191.

40. Batterham RL, Bloom SR. The gut hormone peptide YY regulates appetite. Ann N Y Acad Sci 2003994 162-168. 
498

499

500

501

502

503

504

505

506

507

508

509

510

511

512

513

514

515

516

517

518

519

Figure 1. Acute insulinotropic effects of FFAR4 agonists (A, C) Compound A and (B, D) GSK137647 alone and in combination with FFAR4 antagonist AH-7614 (10 $\left.0^{-5} \mathrm{~mol} / \mathrm{l}\right)$ or FFAR1 antagonist GW1100 $\left(10^{-5} \mathrm{~mol} / \mathrm{l}\right)$ at $5.6 \mathrm{mM}$ and $16.7 \mathrm{mM}$ glucose in clonal pancreatic BRINBD11 cells. Alanine $(10 \mathrm{mmol} / \mathrm{l})$ was used as positive control. MTT cell viability analysis demonstrating cytotoxicity of (A, C) Compound A and (B, D) GSK137647 on BRIN-BD11 cells. Hydrogen peroxide $(1 \mathrm{mmol} / \mathrm{l})$ was used as a positive control. Values are mean $\pm \mathrm{SEM}$ $(\mathrm{n}=8)$ for insulin secretion and $(\mathrm{n}=4)$ for cell viability. ${ }^{*} \mathrm{p}<0.05, * * \mathrm{p}<0.01, * * * \mathrm{p}<0.001$, compared to saline control. $\uparrow \mathrm{p}<0.05, \dagger^{\dagger} \mathrm{p}<0.01, \dagger_{\dagger}+\mathrm{p}<0.001$, compared to agonist alone.

Figure 2. Localisation of (A, B) 4', 6 diamidino-2-phenylindole (DAPI) nuclear stain, (C, D) FFAR4, (E, F) insulin and $(\mathrm{G})$ double immunofluorescence of FFAR4 and insulin in high fat fed $(\mathrm{A}, \mathrm{C}, \mathrm{E}, \mathrm{G})$ and lean $(\mathrm{B}, \mathrm{D}, \mathrm{F}, \mathrm{H})$ pancreatic islets at $\mathrm{X} 40$ magnification. Examples of double immunofluorescence indicated by white arrows. qPCR and western blot analysis demonstrating the effect of FFAR4 agonist treatment on FFAR4 mRNA and protein concentrations at $(\mathrm{I}, \mathrm{K}) 5.6 \mathrm{mM}$ and $(\mathrm{J}, \mathrm{L}) 16.7 \mathrm{mM}$ in clonal pancreatic BRIN-BD11 cells after $4 \mathrm{~h}$ treatment. Expression was normalised to GAPDH for qPCR $(\mathrm{n}=3)$ and $\beta$-actin for western blotting ( $\mathrm{n}=2$; two independent experiments with two technical replicates). Values are presented as mean \pm SEM. ${ }^{*} \mathrm{p}<0.05, * * \mathrm{p}<0.01$, compared to glucose control.

Figure 3. Acute effects of FFAR4 agonists Compound A and GSK137647 on plasma glucose $(\mathrm{A}, \mathrm{C})$, insulin $(\mathrm{B}, \mathrm{D})$ and respective AUC $(\mathrm{E}-\mathrm{H})$. Glucose $(18 \mathrm{mmol} / \mathrm{kg} \mathrm{bw})$ was administered orally alone or in combination with FFAR4 agonist Compound A or GSK137647 $(0.1 \mu \mathrm{mol} / \mathrm{kg}$ bw) and either the FFAR4 antagonist AH-7614 (0.1 $\mu \mathrm{mol} / \mathrm{kg}$ bw) or Sitagliptin $(50 \mathrm{mg} / \mathrm{kg} \mathrm{bw})$ to HFF mice $(n=6)$. Values are presented as mean \pm SEM. ${ }^{*} p<0.05, * * p<0.01, * * * p<0.001$, 
compared to HFF glucose control. $\dagger \mathrm{p}<0.05$, $\dagger \dagger \mathrm{p}<0.01$, $\uparrow \dagger \uparrow \mathrm{p}<0.001$, compared to agonist 521 alone

522

523

524

525

526

527

Figure 4. Acute effects of FFAR4 agonists Compound A and GSK137647 (0.1 $\mu \mathrm{mol} / \mathrm{kg}$ bw) on circulating (A, D) total GLP-1, (B, E) total GIP and (C, F) DPP-IV activity. Glucose (18 mmol/kg bw) was administered orally alone or in combination with FFAR4 agonist to HFF mice $(n=6)$. Values are presented as mean \pm SEM. ${ }^{*} \mathrm{p}<0.05, * * \mathrm{p}<0.01, * * * \mathrm{p}<0.001$, compared to HFF glucose control.

Figure 5. Acute effects of i.p. administration of FFAR4 agonists Compound A and GSK137647 $(0.1 \mu \mathrm{mol} / \mathrm{kg}$ bw) on (A) glucose tolerance and (B, C) cumulative food intake. Glucose (18 mmol/kg bw) was administered i.p. in combination with FFAR4 agonist to lean Swiss TO mice for glucose tolerance $(n=6)$. For satiety analysis, FFAR4 agonists were orally administered alone or in combination with DPP-IV inhibitor (Sitagliptin) to $18 \mathrm{~h}$ fasted lean Swiss TO mice. ${ }^{*} \mathrm{p}<0.05,{ }^{* *} \mathrm{p}<0.01,{ }^{* * *} \mathrm{p}<0.001$, compared to saline control. $\dagger \mathrm{p}<0.05$, $\dagger \dagger \mathrm{p}<0.01, \dagger^{\dagger}+\mathrm{p}<0.001$, compared to agonist alone.

\section{Supplementary data}

Figure 1. Effects of Compound A and GSK137647, with half maximum effective concentration $\left(\mathrm{EC}_{50}\right)$ values, on insulin release from clonal pancreatic BRIN-BD11 cells at (A) 5.6 $\mathrm{mM}$ and (B) $16.7 \mathrm{mM}$ glucose concentrations. Results are the mean $\pm \operatorname{SEM}(\mathrm{n}=8)$.

Figure 2. Effect 150-day high fat fed diet on glucose tolerance and insulin secretion in $18 \mathrm{~h}$ fasted Swiss TO mice. Animals were subjected to an oral glucose tolerance test $(18 \mathrm{mmol} / \mathrm{kg}$ bw) with (A, B) glucose tolerance, (C, D) insulin secretory response, (E) fasting plasma glucose 

$* * * \mathrm{p}<0.001$ compared to lean control.

544 Figure 3. Effect 150-day high fat fed diet on glucose tolerance and insulin secretion in $18 \mathrm{~h}$ 545 fasted Swiss TO mice. Animals were subjected to an insulin sensitivity test (40U/kg 546 bodyweight; dissolved in $0.9 \%$ saline, i.p. injection). (A) Plasma glucose and (B) respective 547 AOC are shown. Results are mean $\pm \operatorname{SEM}(n=8) . * * p<0.01$, compared to lean control. 

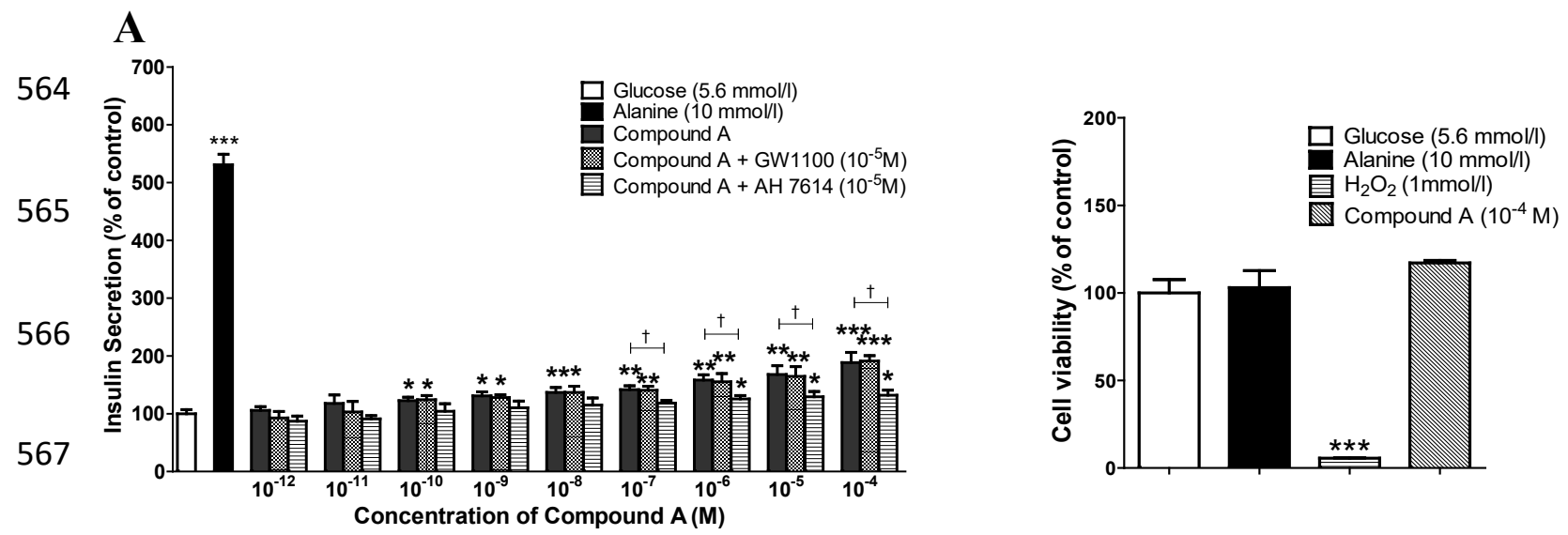

568

569

570

571

572

\section{B}

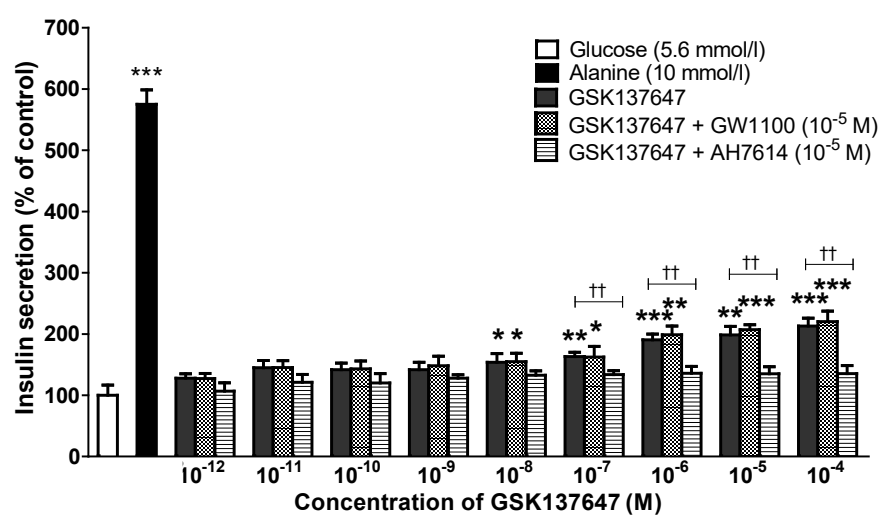

573

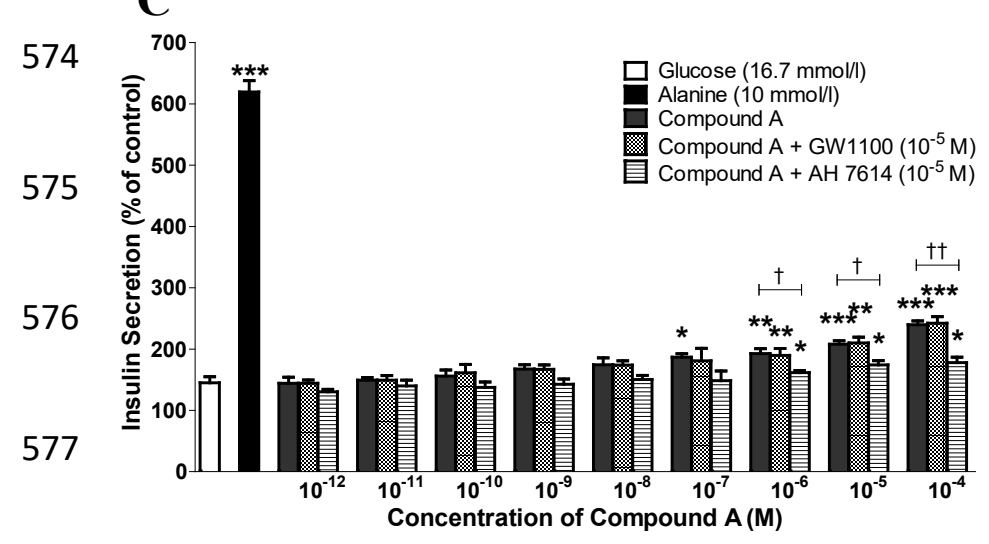

578

\section{D}

579

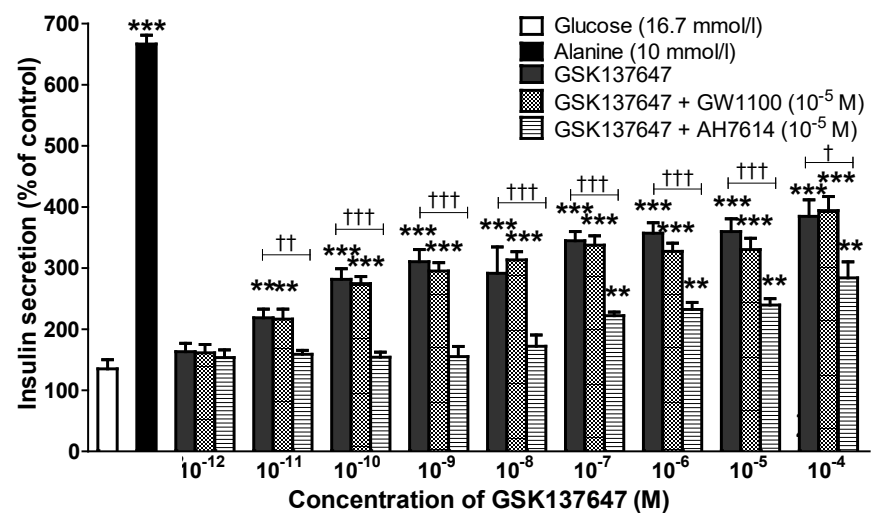

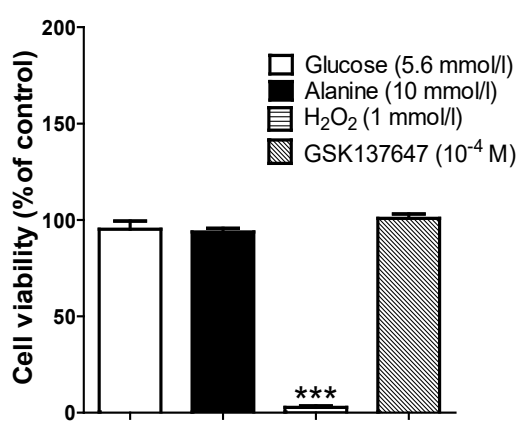
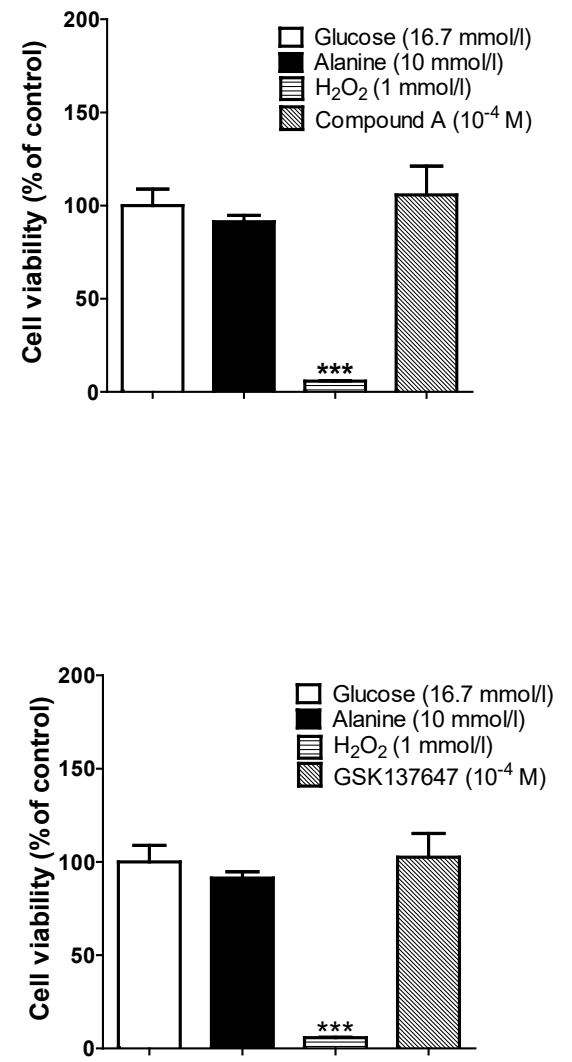
Figure 2.

583

584

585

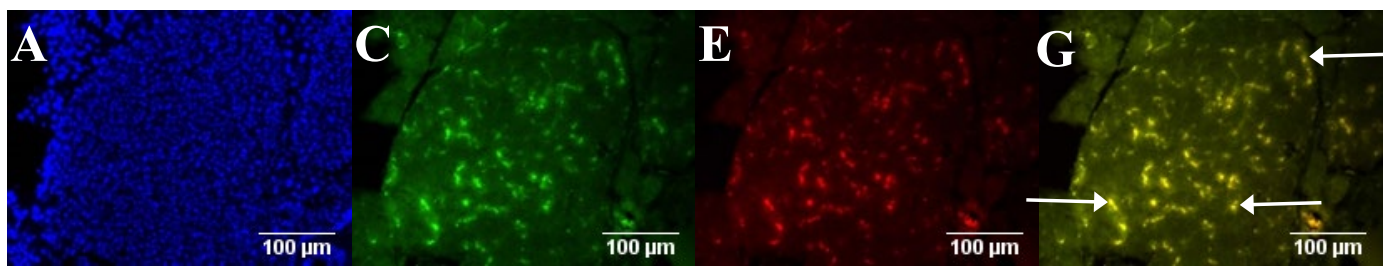

586

587

588

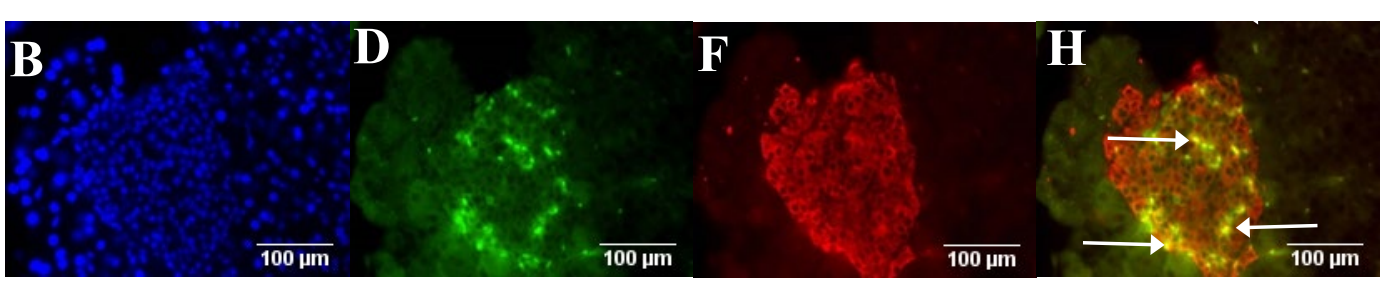

589

I

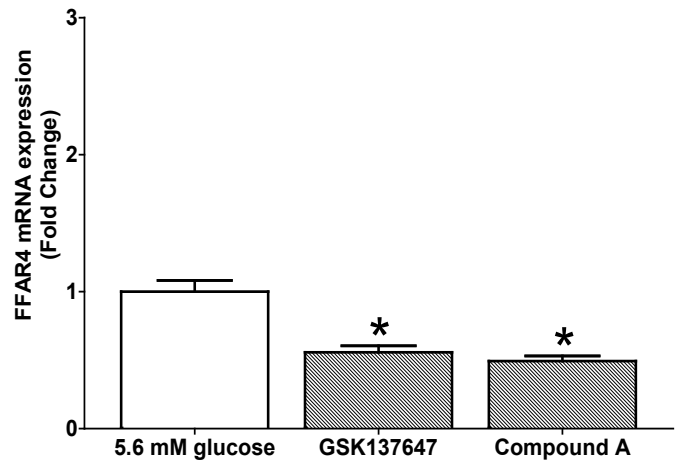

593

K

594

595
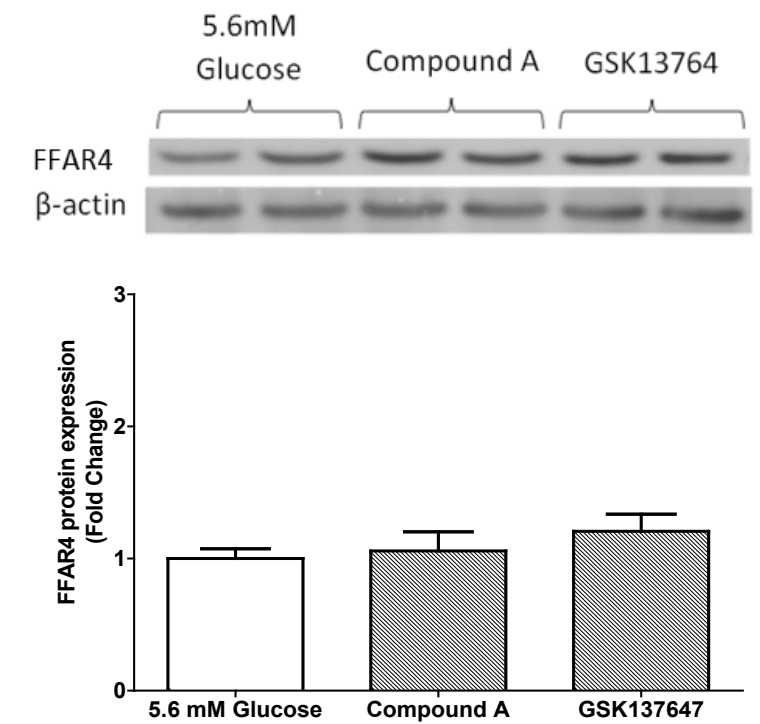

J

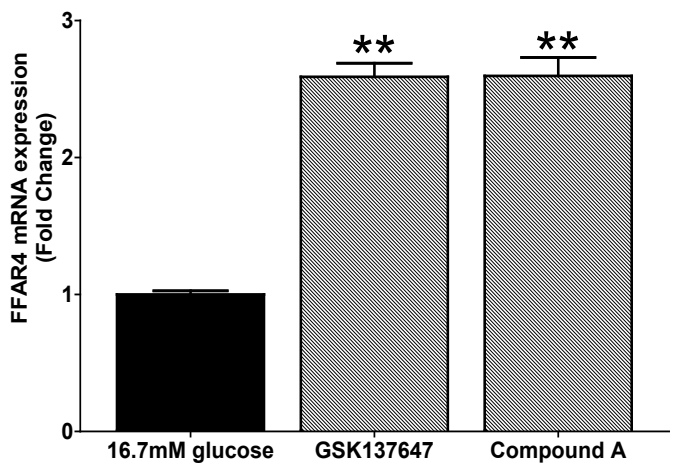

L
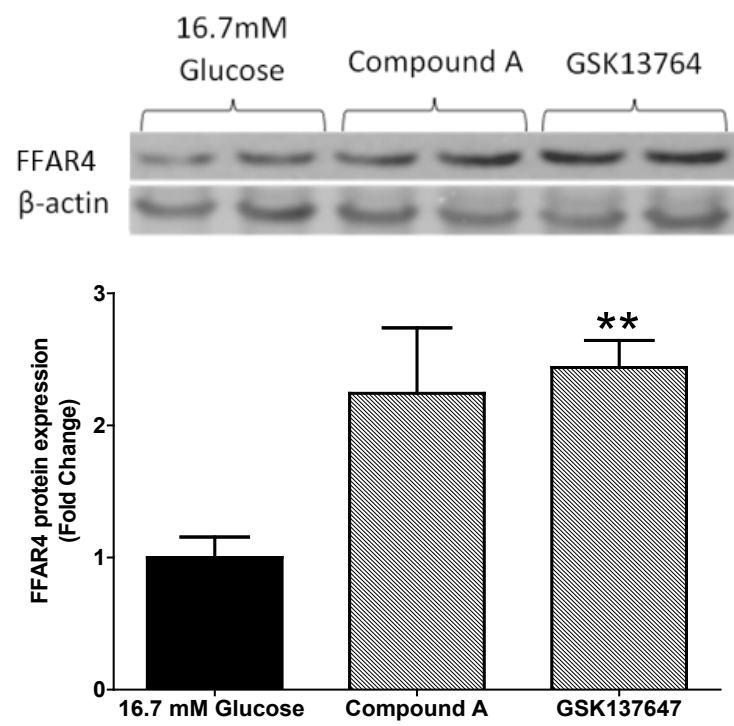
Figure 3.
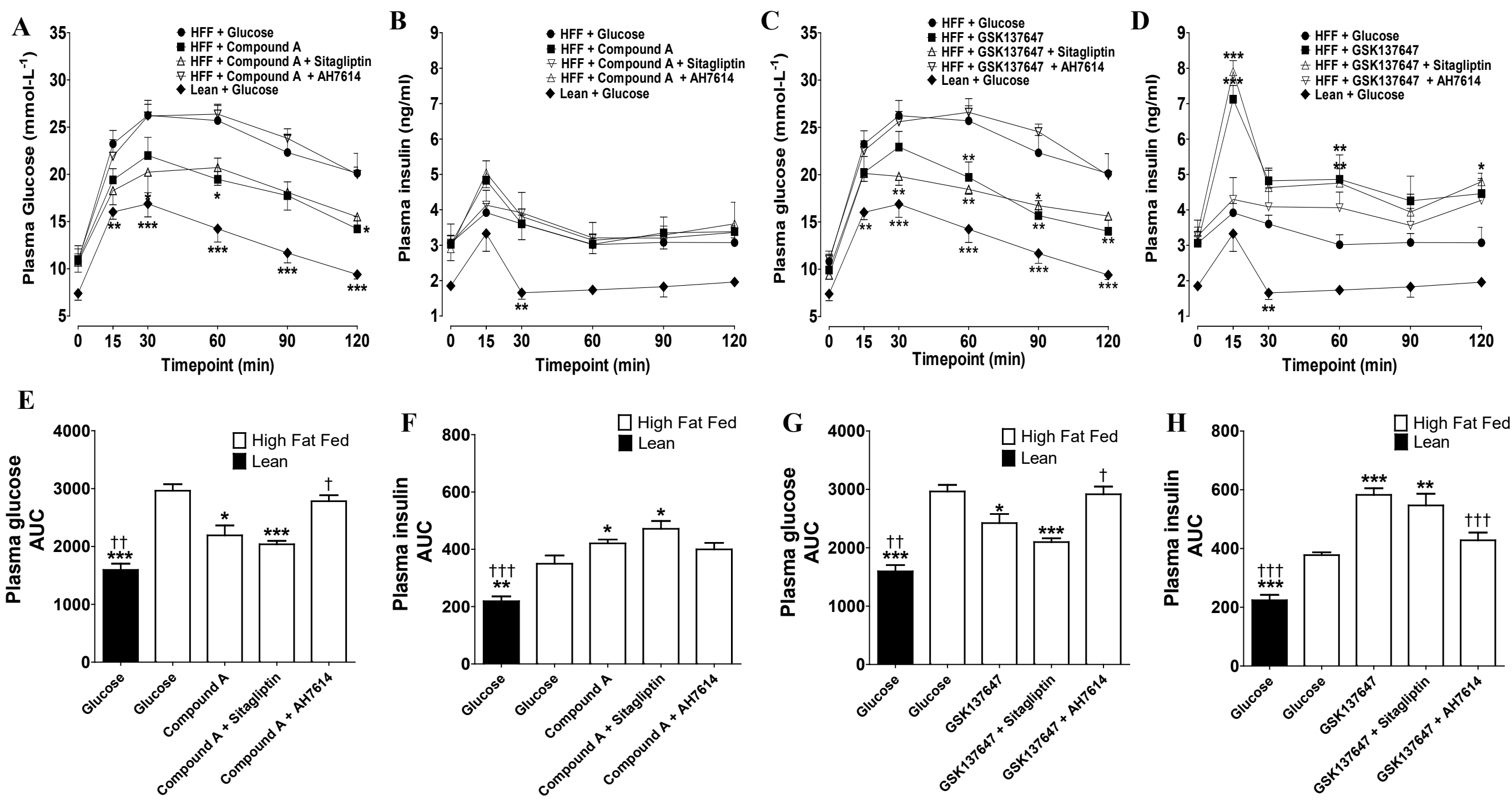
Figure 4.
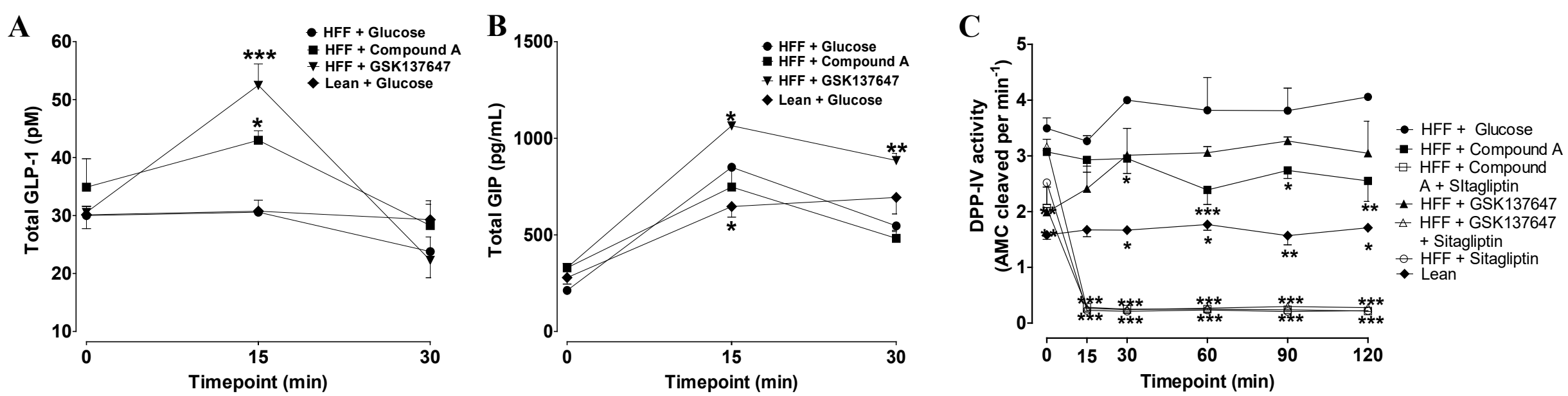

D

E

F
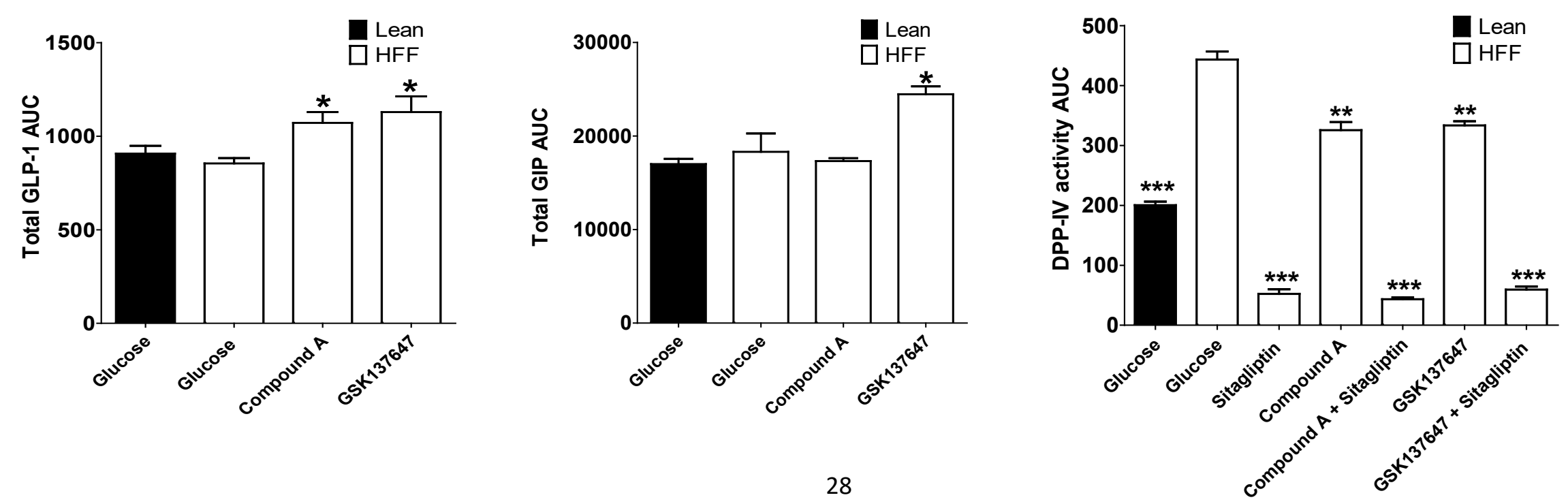
Figure 5
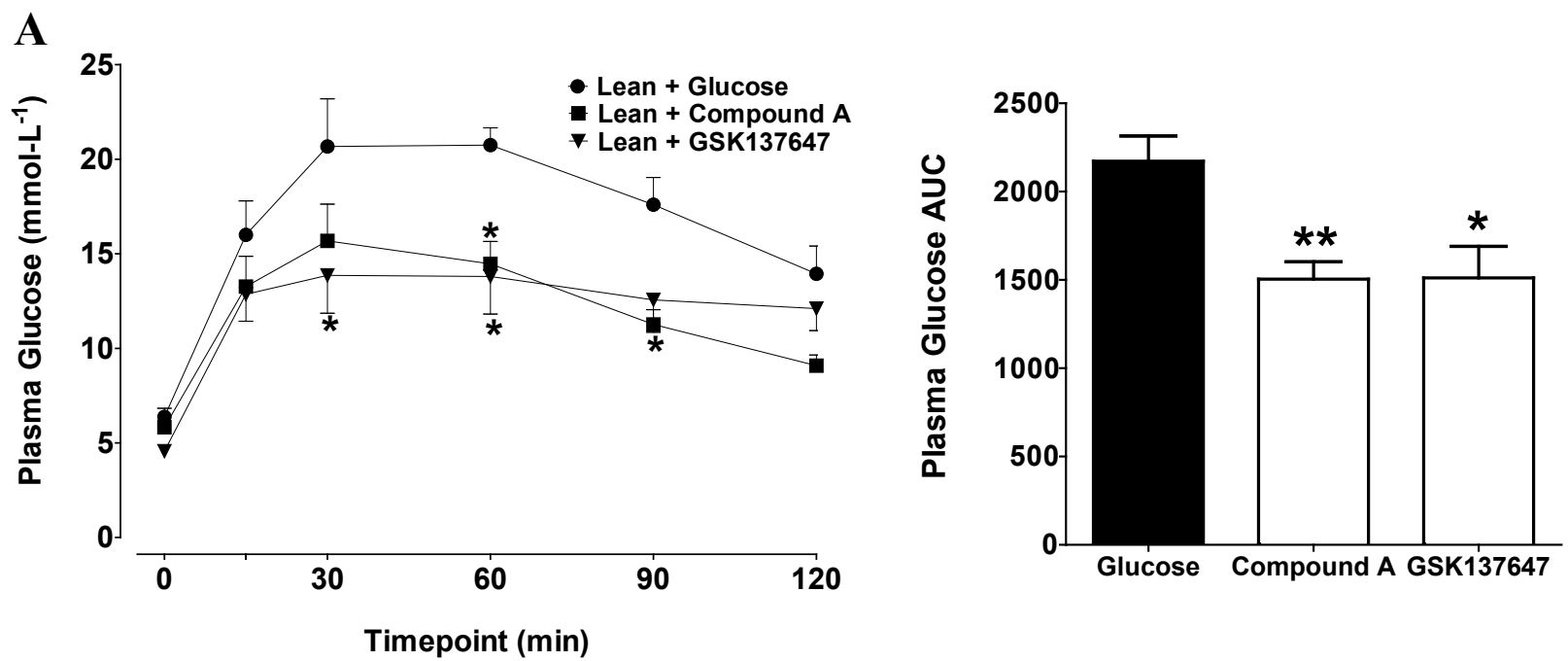

B

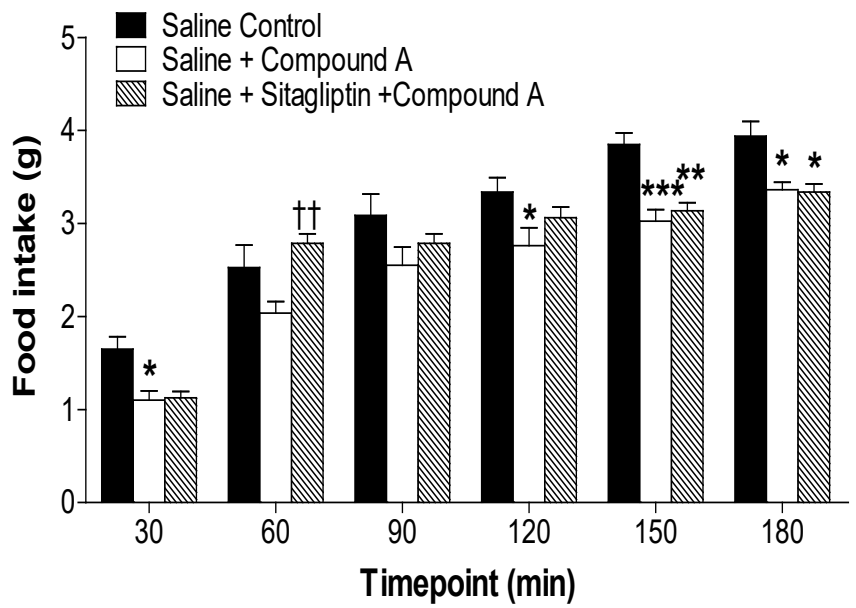

C

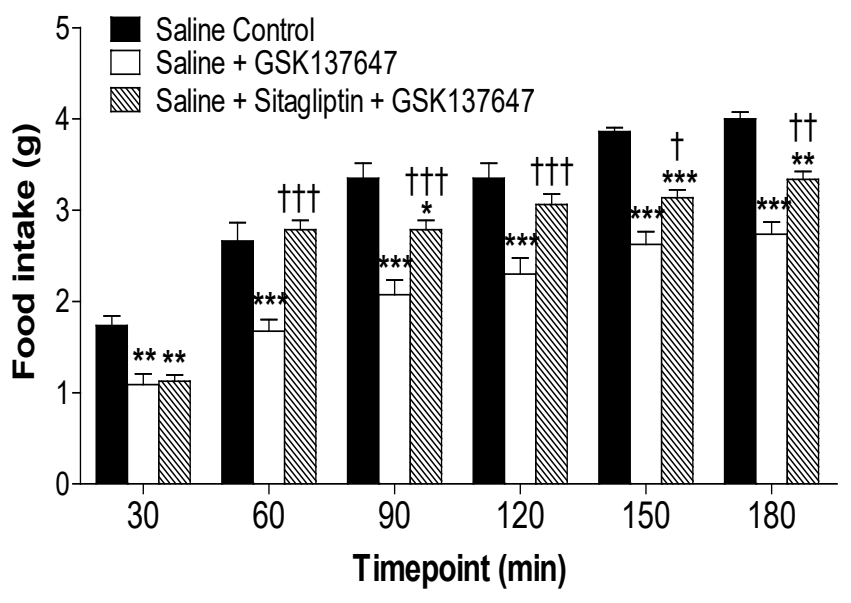




\section{Supplementary material}

\section{Figure 1}

A

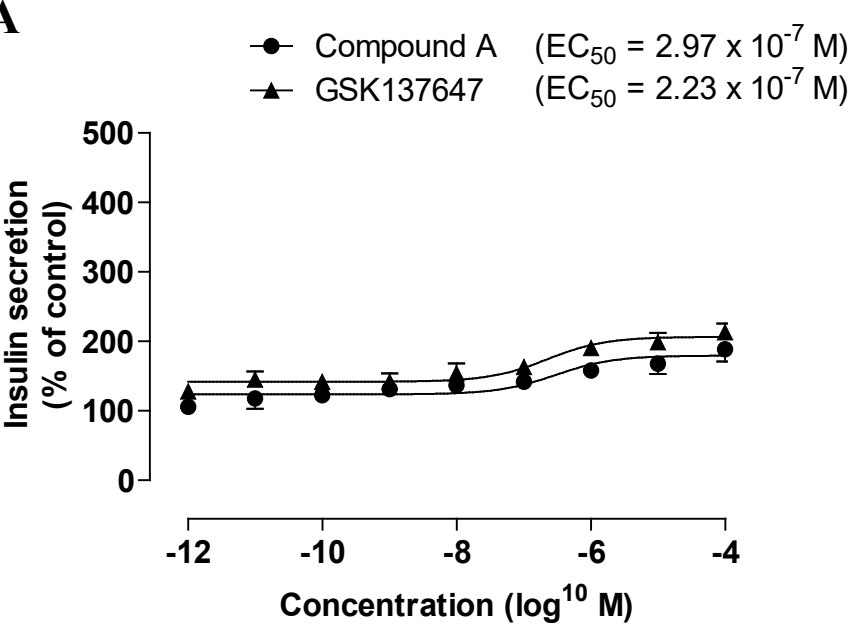

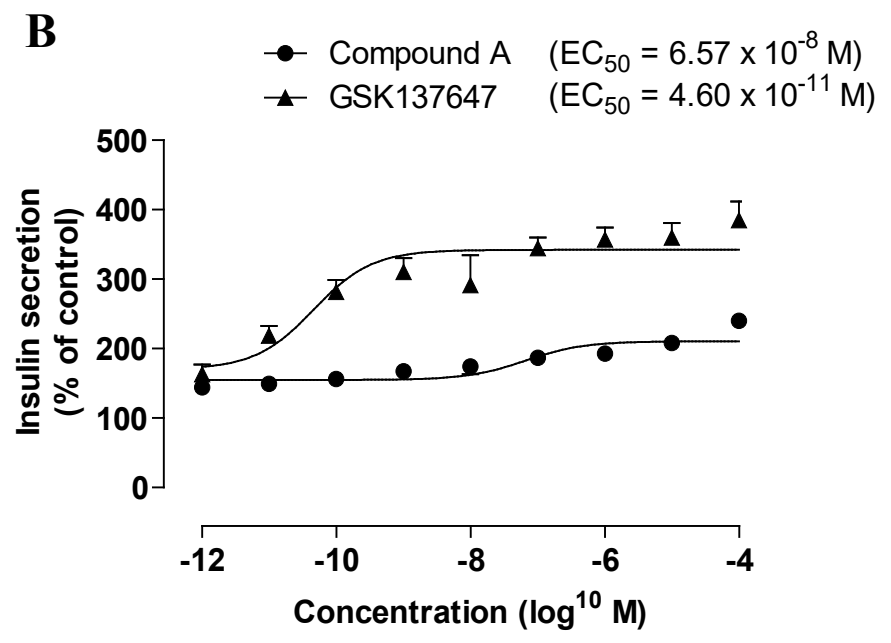


Figure 2

A

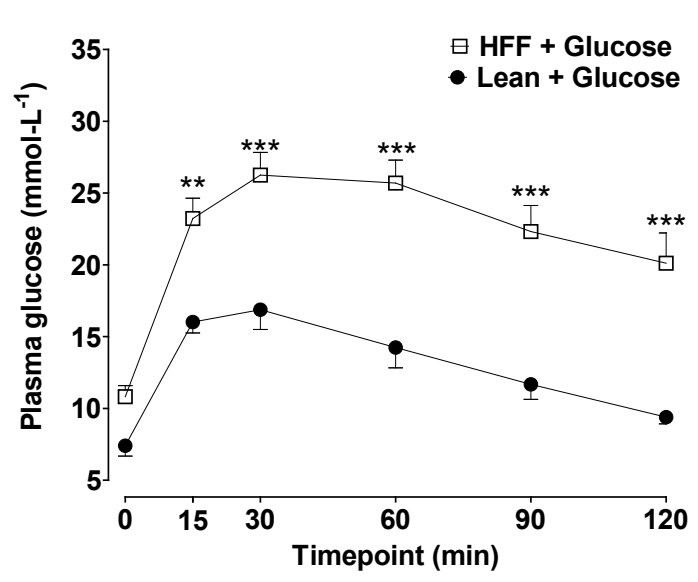

B

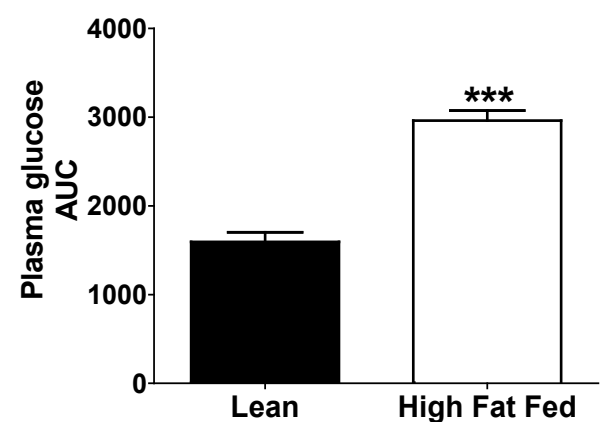

C

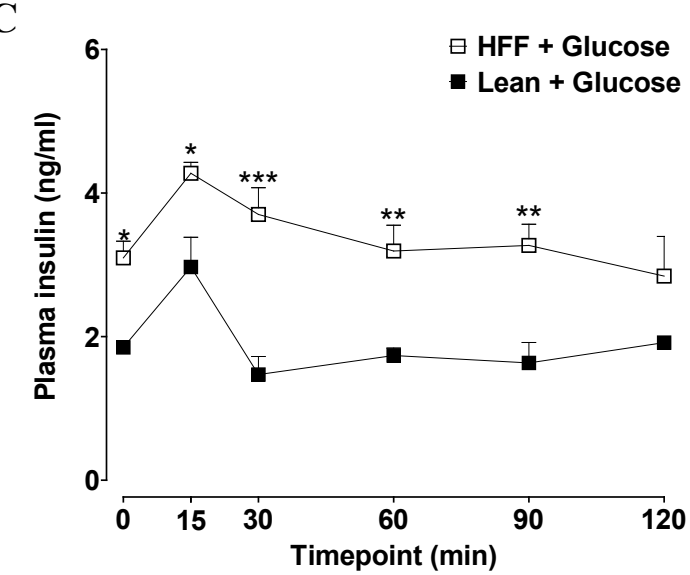

D

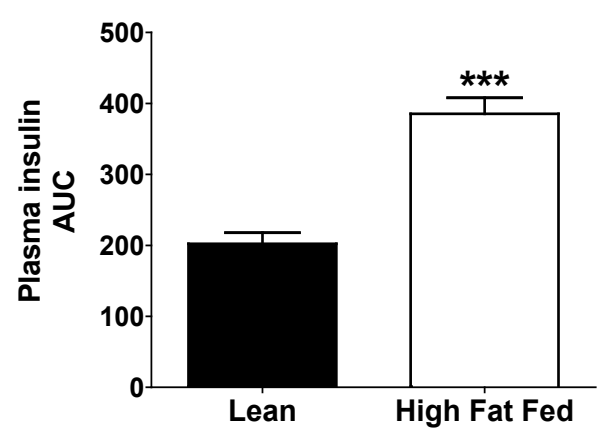

E
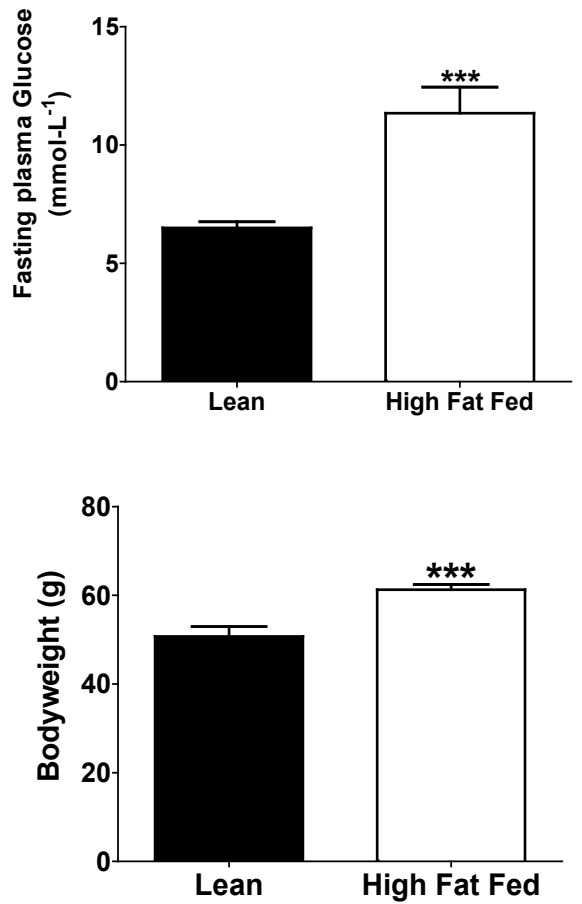
Figure 3

A

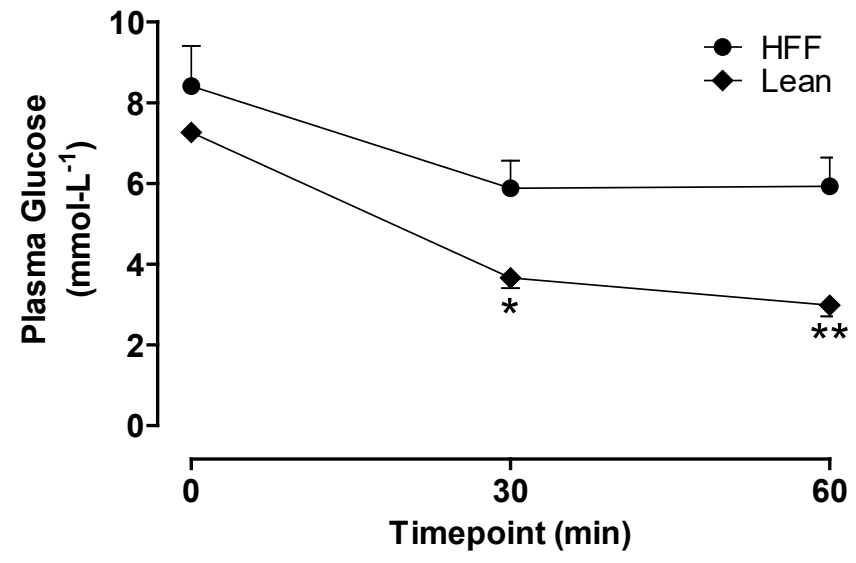

B

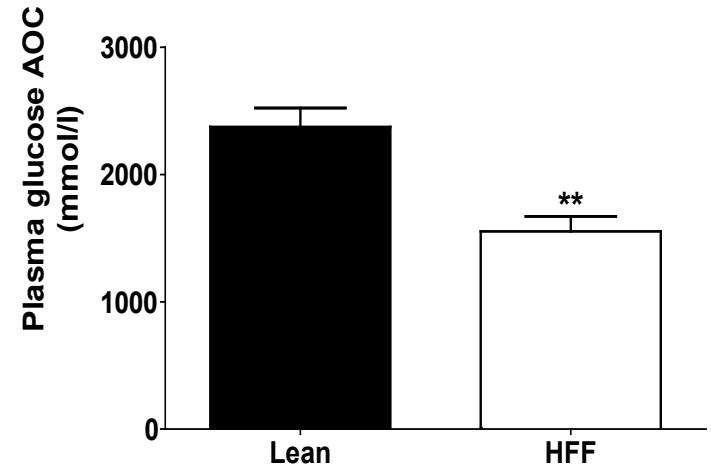

